九州大学学術情報リポジトリ

Kyushu University Institutional Repository

\title{
On The Disintegration of Rice Straw
}

Iwata, Hisayoshi

Laboratory of Animal Nutrition, Department of Agriculture, Kyushu Imperial University

https://doi.org/10.5109/22329

出版情報: 九州大学大学院農学研究院紀要. 1 (6)，pp.217-240，1926-05. Kyushu Imperial University バージョン：

権利関係 : 
Journal of the Department of Agriculture, Kyushu Imperial University, Vol. I, No. 6 May $2.5,1926$

ON THE DISINTEGRATION OF RICE STRAW

\author{
Hisayoshi Iwata
}

\title{
1. INTRODLCIION
}

Japanese agriculture consists principally of cropping, and the rice plant is the most important and extensively cultivated throughout the country. On the other hand live stock farming is very poor compared with that of foreign countries, and the farmers of this country utilise their live stock chiefly for agricultural work and for obtaining farm yard manure.

In winter they feed their farm animals mainly on rice straw mixed with rice bran and various other byproduct-fodders. In summer they use grass growing on uncultivated lands and dykes and ditches of paddy land, together with rice straw. Also they use a small amount of soy bean, barley, ctc. as concentrated fodder for the draught animals.

Rice straw is therefore the most important and essential coarse fodcler, especially in view of the fact that we have scarcely any meadow or pasture land in this country. The straw is generally simply chopped up and given to the cattle, but in some districts of Japan and also of Corea the chopped straw is boiled with water for several hours before being fed to the catle. However this is doubly uneconomical; for boiling the fodder reduces its food value (13) while it requires a considerable amount of fuel. It seems therefore to be very important to settle the question of how the boiling of the straw affects its nutritive value. 
It is also desirable to study some niethod such as straw-disin tegration for improving the focd value of the straw, in orcler to produce an abundant supply of good cuarse fodder. In Germany since 1894 numerous investigations in regard to straw disintegration (7) hase been carried out, and during the great war many sorts of straw were dis integrated on a large scale. The experiments however were made with ryc, barley, oat straw etc. and work with rice straw his never before been attempted (3). Honce the author has studied not only the effect of boiling it with water, but also the action of various dilute alkaline solutions on the composition and nutritive value of the straw.

\section{THE EFFECT OF VARIOUS TREATMENIS ON TIIE INCRLSTING SUBSTANCES OE RICE STRAW}

It is known that the disintegration of the straw is due to the dissolution of incrusting substances and perhaps to the forcing or springing of the bonds uniting them to the other constituents. Accorclingly the effect of various treatments on the incrusting substances was examined.

The straw used was harvested from the neighbourhood of the Kyushu Imperial University in 1923 . Fvery $150 \mathrm{~g}$. of straw, choppecl into $2-3 \mathrm{~cm}$. Jength, was treated with water, or with solutions of sodium hydroxide, sodium carbonate, calcium hydroxide, cither by the cold or hot process, as shown in table II.

The cold process (at $22-25^{\circ} \mathrm{C}$ ) employed was as follows. The sample was put into a large beaker, and soaked in various solutions for $4,6,8$, or 24 hours. The amount of liquid in each case was equivalent in weight to cight tines that of the straw. In the case of the hot procuss ciery $150 \mathrm{~g}$. of the straw was put into a large llask, and 1200 c.c. of water or of one of the solutions $\mathrm{NaOlI}, \mathrm{Na}_{2} \mathrm{CO}_{3}$, $\mathrm{Ca}(\mathrm{OII})_{2}$, of a definite concentration, was poured into it. These mixtures were boiled under a retux condenser, part for 1.5 and part for 4 hours. After being thus treated, the alkaline liquor was filtered through linen, and the straw was thoroughly washed with water until the wash water no longer showed an alkaline reaction, and was then dried in the air.

This disintegrated straw had a clear yellowish green colour as long as it showed an alkaline reaction; but when neutral it became 
dark brown. The brittleness of the disintegrated straw graclually increased as the degree of disintegration proceeded.

Each of the samples thus obtained was submitted to tests for the determination of ash, silica, lignin and the chlorine number.

Proceding the determination of Iignin (8), the author compared the WIlcstärates method which uses $42 \% \mathrm{HCl}(16)$, with the OsT

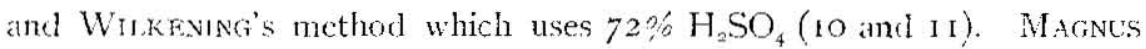
(9) employed the former method in his investigation, and $\Lambda$ RculbaLl employed the latter, after modifying it limself ( 1 ). He diluted the hydrolysed solution with ordinary tap water to a strength of $3 \%^{\circ}$ of sulfuric acid and filtered with linen and a gooch crucible, but the author difuted with distilled water and filtered with ordinary filter paper.

With five sorts of disintegrated straw the following results were obtained.

Table I. Comparison of WrLLstätter's method with Ost-Wilkexing's method.

\begin{tabular}{|c|c|c|c|}
\hline No of sample & WILISTATTER-Lignin & $\begin{array}{c}\text { OST-WILKENING- } \\
\text { Lignin }\end{array}$ & Ratio $=\frac{\text { W-Jignim }}{\text { O-Lignin }}$ \\
\hline । & I 2.55 & 1.3 .45 & 0.933 \\
\hline 2 & 12.41 & 1309 & 0.948 \\
\hline 3 & 12.27 & 1.3 .08 & $0.93^{8}$ \\
\hline 4 & I 167 & 12.26 & $0.95^{2}$ \\
\hline 5 & 10.01 & 10.49 & 0.954 \\
\hline Average & & & 0.945 \\
\hline
\end{tabular}

From this tablc it is seen that the results of these two methods coincide well with cach other, deviating only by 5 per cent. Therefore the author employed the simpler and easier method namely OsrWILKENING'S.

The chlorine number was measured by a modification of the method of WAENTIG and CIERISCH ( 14 and 15 ), the principle of which consists in the combination of chlorine with lignin. The method in bricf was as follows: Io $\mathrm{g}$. of coarsely rilled straw was put into a chlorine absorption cylinder and moistened with $20 \mathrm{cc}$. of $1 \%$ hydrochloric acid solution. The chlorine gas, saturated with water vapor, was passed through the straw for 30 minutes, then air was passed through for $I_{5}$ minutes in order to expel the excess of chlorine gas remaining in the absorption cylinder, and then the amount of chlorine absorbed was measured. The amount of maximum, absorption in percentage gave the chlorine number. 
Table II The incrusting substances of the treated straw

\begin{tabular}{|c|c|c|c|c|c|c|c|c|c|c|c|}
\hline \multicolumn{4}{|c|}{ Treatments } & \multicolumn{4}{|c|}{ Incrusting substances $\%$} & \multirow[b]{2}{*}{ Vield \% } & \multicolumn{3}{|c|}{ Loss $\%$} \\
\hline Reagent & $\begin{array}{l}\text { Concen- } \\
\text { tration }\end{array}$ & $\begin{array}{c}\text { Tempera- } \\
\text { ture }\end{array}$ & Hours & Ash & Silica & I.ignin & Cl-number & & Ash & Silica & L,ignin \\
\hline \multicolumn{4}{|c|}{ Untreated straw } & 20.13 & $|17.52|$ & 14.69 & 19.4 & 100.00 & - & 一 & - \\
\hline Water & $\ldots$ & $22.25^{\circ} \mathrm{C}$ & 4 & 19.63 & $17 \cdot 45$ & $14.3^{6}$ & 13.4 & 90.81 & 2.33 & 1.67 & 1.65 \\
\hline$"$ & - & Boiling $r$ & " & 13.46 & 16.72 & 14.35 & $\mathbf{I} \delta .1$ & 85.92 & 4.27 & 3.15 & $2.3^{6}$ \\
\hline $\mathrm{NaOII}$ & 0.25 & $22-25^{\prime 2}$ & 4 & 15.33 & $13 \cdot 4^{8}$ & $\mathrm{I} 4.47$ & $1 \% .4$ & 85.63 & $7.0 \mathrm{I}$ & 5.95 & $2.3^{\circ}$ \\
\hline ” & 0.50 & , & , & 15.56 & 13.47 & $\mathbf{1} 4.34$ & 190 & $83 \cdot 33$ & 7.16 & 6.30 & 2.74 \\
\hline$"$ & 1.00 & " & $"$ & I I. 44 & 9.39 & $1.3 .4^{8}$ & 16.2 & 75.73 & $11.4^{6}$ & 10.40 & 4.47 \\
\hline$"$ & 1.50 & , & " & 10.13 & $8.3 \mathrm{r}$ & 12.29 & 14.4 & 71.66 & $\mathrm{I} 2.35$ & 11.55 & 5.66 \\
\hline ", & 2.00 & $"$ & ", & 10.22 & 8.19 & II. 52 & $\mathrm{I} 2.7$ & 60.12 & 13.07 & 11.66 & 6.73 \\
\hline $\mathrm{NaOlI}$ & 0.50 & $22-25^{\circ}$ & 8 & $\mathbf{1} 5.83$ & 13.97 & 14.19 & 17.0 & 6.22 & 7.07 & 6.03 & 3.02 \\
\hline , & 100 & ", & " & 10.36 & 8.50 & 13.33 & 15.6 & $73 \cdot-27$ & 12.54 & 11.29 & 4.92 \\
\hline$"$ & 1.50 & " & $"$ & 9.20 & 7.09 & 11.95 & 13.5 & $f(x) .72$ & 1.3 .72 & $\mathrm{I} 2.5^{6}$ & 6.36 \\
\hline ", & 2.00 & " & $"$ & 10.56 & 7.66 & II.12 & 12.2 & $6,7.20$ & I2.97 & $1=.37$ & 7.22 \\
\hline $\mathrm{NaOH}$ & 0.50 & $22-25$ & 24 & I 6.49 & $\mathrm{I} 3.9 \mathrm{I}$ & 13.74 & 16.7 & 32.67 & 6.50 & 6.02 & 3.33 \\
\hline$"$ & I.co & " & $"$ & 9.03 & 6.75 & 13.38 & $I=.7$ & 75.42 & $13.6 \%$ & 12.70 & 5.13 \\
\hline " & 1.50 & , & " & 6.04 & 3.92 & I I.O9) & 13.7 & 65.13 & 16.20 & I 4.97 & $7 \cdot 47$ \\
\hline $\mathrm{NaOH}$ & 0.50 & Boiling $P$ & 4 & 18.51 & 16.46 & 0.74 & 10.0 & $3 \mathrm{I}$ & 7.12 & 5.95 & $7 . \% 4$ \\
\hline ", & 0.50 & , & 1.5 & $17 \cdot 78$ & 15.65 & I 1.68 & 13.6 & 78.52 & 6.17 & 5.23 & 5.52 \\
\hline$"$ & I.co & ", & " & $\mathrm{I} 2.46$ & 10.95 & 9.19 & 10.2 & $66.7^{6}$ & 11.31 & $\mathrm{I} 0.2 \mathrm{I}$ & 8.55 \\
\hline $\mathrm{Na}_{2} \mathrm{CO}_{3}$ & o. & $22-25^{\circ}$ & 6 & 17.94 & I6.56 & 14.33 & 9.3 & 26 & $4, \hat{o}_{3}$ & $3 \cdot 3$ & 2.47 \\
\hline$"$ & 1.33 & , & ", & 18.31 & 15.40 & I 4.34 & 19.3 & 40 & $4.4 i$ & $4 \cdot 36$ & 2.43 \\
\hline$"$ & 199 & $"$ & $"$ & 18.44 & 14.44 & 14.41 & I $9 . \mathrm{I}$ & 3.41 & 4.75 & $5.4^{\circ}$ & 2.67 \\
\hline $\mathrm{Na}_{2} \mathrm{CO}_{3}$ & 0.66 & Boiling $P$. & 1.5 & 18.17 & 15.92 & 12.50 & 14.5 & 77.19 & 6.10 & 5.23 & 5.04 \\
\hline " & I 33 & ", & " & $17.0 \hat{01}$ & I 5.67 & II. I6 & 1.3 .1 & 73.79 & 6.99 & 5.96 & 6.46 \\
\hline$"$ & 1.99 & " & " & 17.30 & 15.20 & 10.18 & $\mathrm{I}=\mathrm{I}$ & $70.3 \mathrm{I}$ & 7.97 & 6.83 & $7 \cdot 5.3$ \\
\hline $\mathrm{CaO}$ & I.CO & $22 \cdot 25^{\circ}$ & 24 & 30.34 & 13.49 & - & - & 64.37 & 2.97 & 6.14 & - \\
\hline " & 1.25 & , & " & 20.07 & 15.67 & I 2.63 & 15.3 & 83.56 & $3 \cdot 36$ & 4.43 & 4.14 \\
\hline " & 1.00 & Boiling $\mathrm{P}$. & 4 & $22 . j i$ & 14.95 & I 2. of & 1500 & 81.00 & 2.00 & 5.41 & 4.92 \\
\hline "! & 1.25 & $"$ & , & $25.0 \mathrm{I}$ & 16.13 & 12.09 & 15.1 & 76.52 & 0.99 & 5.10 & 5.44 \\
\hline
\end{tabular}


WaENTIG reports that the chlorine number corresponds nearly to $150 \%$ of the amount of WILIsTräter-Lignin, but according to this experiment it was found by measurement to be $120-140 \%$ of the WulstätTER-Lignin, and 1 10-130\% of OST-WILkENIng-Lignin. However, the amount of lignin and the chlorine number were nearly proportional to each other.

The results of analysis together with the decrease of the incrusting substances during the disintegration process are shown in table II, in lry matter percentages.

When the straw was only immersed in distilled water for 4 hours, a slightly dilute dark brown extract was obtained, but no appreciable decrease in the amount of the incrusting substances or of the chlorine number was obscrved.

When it was boiled with distilled water for 4 hours, there was almost no change compared with the former process, except that the contents of ash and silica were slightly decreased which may be due to the loss of sand adhering to the straw.

When treated with solutions of sodium hylroxicle either by the cold or hot process, the influcnce of concentration on the degree of disintegration was very remarkable In the case of the cold process such dilute solutions as 0.25 or $0.5 \%$ of sodium hydroxide dicl not affect the amount of silica and lignin or the chlorine number; however the disintegration increased sudtenly when the concentration became higher than $1 \%$ of sodium hydroxicle, but was not proportional to the concentration. The analysis of the results of disintegration with cold sodium hydroxide solution indicates that the content of silica was always less than that of lignin, while all the other cisintegrated straw showed the revere. The maximum extraction of silica was already reached when treated with the $1.5 \%$ caustic soda solution for 4 or 8 hours; actualiy more than half of the total silica contained in the straw was removed. As regards the extraction of Jignin it differed somewhat from that of silica, in that it was not noticeably promoted, even when the concentration of the reagent was increased as high as I.5 or $2 \%$ sodium hyclroxide; also its loss in percentage was so small that it dicl not reach half of that of the silica.

When boiled with $05 \%$ or $1 \% \circ$ caustic soda solution, part for I 5 , past for 4 hours, the loss of silica was smaller than when treated by the cold process, on the contrary the lignin and chlorine number decreaced very remarkably compared with the cold process. 
When immersed for 6 hours in one of the following cold sodium carbonate solutions $0.66, \mathrm{I} .33$ and $\mathrm{I} .99^{\circ}, \mathrm{n}$ of $\mathrm{Na}_{2} \mathrm{CO}_{3}$, equivalent respectively to $0.5, \quad 10$ and $1.5 \%$ of $\mathrm{NaOH}$, in every case there was no remarkable effect on the content of lignin and the chlorine number, but the amount of silica slightly decreased. On the of her hand when boiled with the same sodium carbonate solution as above for 1.5 hours, the dissolution of lignin was much accerelated, while scarcely any silica was eliminated.

When treated with calcium hydroxide, only slight boses of ash and silica were observed and sometimes the content of ash showed a little incrase, because the calcium hydroxide could not be thoroughly washed out. But the content of lignin and the chlorine number considerably decreased, and their numerical value approximated to that of the straw which was treated with sodium hychoxide solution (1.0 or $1.5 \% \mathrm{NaOH}$ ) at ordinary temperature.

From the above facts, the following statements can be made.

I) It was hardly possible to disintegrate the rice straw with cold or boiling water or with solution of $025,0.5 \% 0$ sodium hydroxide ancl $066,1.33$, r.99:5 solium carbonate, at ordinary temperature.

2) When treated with solutions that contain more than 10,6 of sodium hydroxide, the amount of both lignin and silica were considerably decreased.

3) When disintegrated with boiling milk of lime ( 1 o or $1.25^{\circ} \circ \mathrm{CaO}$ ) a considerable portion of the lignin was removed, but the silica was scarcely touched.

4) When boiled with the solution of sodium hydroxide and sodium carbonate, a noticeable quantity of lignin was extracted, comparet with the cold process.

5) As regaris the influence of the lime of treatment with cold sodium hydroxide solutions upon the dissolution of the incrusting substances, the greatest amount of dissolution took place in the first four hours ( 2 and 5)

\section{THE EFFECT OF THE TREATMENT ON THE COMPOSITTON ANI NUTRITTE VALUE OF THE RICE STRAW}

The quantitative effect of several treatments on the incrusting substances of straw having been studied, the author now tricd to find out the effect of these treatment on the nutritive value.

The samples wore prepared as follows. 
1) Untreated rice straw :-The same as that employed for the previous experiments.

2) Boiled straw :-Every 2 kilos of chopped straw were boiled with I6 liters of water, kceping up the amount of water by supplying hot water, for 3 hours with frequent stirring. The brown liquor was then drained off The straw was washed with water and then dried at $50-60^{\circ} \mathrm{C}$. This boiled straw became dark brown and fragrant. Rams and catte rather prefered the wot boiled straw to the dry.

3) Soda straw I :-Every 6 kilos of the chopped straw was put into a large pot, about 60 litcrs capacity, provided with an outlet tap at the bottum to drain off the lye and wash water. Then $4^{8}$ liters of 075 ?' caustic soda solution, weighing 8 times as much as the straw were added, and thoroughly stirred. The mixture was allowed to stand for 3 lours, uncler the pressure of a weight stone, at ordinary temperature $20^{\circ} \mathrm{C}$. The alkaline dark brown liquor was completely drained off and the straw was thoroughly washed until the wash water showed a neutral reaction, and then dried in the air. This soda straw I. had a dark brown colour and fragrant odour; its original form was not changed but it became somewhat brittle. Rams and cattle ate it readily either wet or dry.

4) Soda straw II :- lreated with $1.5 \%$ caustic soda solution at ordinury temperature $20^{\circ} \mathrm{C}$, with the same procedure as above. This preparation hac the same appearence as the straw $I$, and was eaten readily by rams and catte.

5) Soda straw III. - - Treated with $0.25^{\circ}{ }^{\prime}$ caustic soda solution at $8^{\circ} \mathrm{C}$. by the same procelure as above, and dried at $50-60^{\circ} \mathrm{C}$. This preparation was dart brown and as hard as the originat straw. The rams and cattle showed as little relish for it as for the untreated straw cither in the wet or dry state.

6) Lime straw:-Lvery 2 kilos of chopped straw was boiled with i 6 liters of water and $160 \mathrm{~g}$. of calcium hydroxide for 3 hours with frequent stirring. It was then washed with water until the wash water became colourless. This air dried line straw lost the lustre

\footnotetext{
1) Afterwards the straw, thus treated and containing abeut $80 \%$ of moisture was fed to a cow and a horse at the Imperial College of Agricultre and Forestry in Noriskia, and they atc 10-15 kilos of it per day, mixed with concentrated fodder.
} 
of the origsinal straw, and became fragrant and brittle. Rams and cattle liked it and ate it readily in cither the wet or dried form. ${ }^{2}$

Proceding the determination of the nutritive value, these six preparation wete analysed in the usual way, crude fiber being determined by the Wefnne process, and the protein by STCTzER-Barnstein's method. The results of analysis are shown in tabie VII.

In order to investigate the nutritive value, the digestion coefficients were estimated according to the ordinary method. Two rams were kept in the feeding box and fed on a definite ration of fodder. After the preliminary period of 5-8 days, the main period was continued for io days. The faeces were collected during the main period every day, and $1 / 10$ of its amount was dried at $55-60^{\circ} \mathrm{C}$, and then submitted to the usual analysis. Since both the untre.ted and treated straws were very poor in protein, Cenge hay (Astragalus sinicus L.) which was made at the Farm of the Cniversity in June 1924, was given together with the sample, mixed with ro $\mathrm{g}$. of common salt. All of these fodders were completely consumed by the rams in every case. In the first fecling experinent the digetion coefficients of Genge hay were ascertained, and then those of the other six sample fodders were determined one after another.

The rations of each period and the dry matter contents of each fodder are shown in the next table.

Table III. The rations of each period

\begin{tabular}{|c|c|c|c|c|c|}
\hline \multirow{2}{*}{ Period } & \multirow{2}{*}{ Foulder } & \multirow{2}{*}{$\begin{array}{c}\text { Dry matter } \\
\%\end{array}$} & \multicolumn{3}{|c|}{ Weight $\mathrm{g}$. } \\
\hline & & & Ram No. I. & Rarr & 11 Yo. 11. \\
\hline 1 & Genge hay & 86.38 & $7 \mathrm{co}$ & & 700 \\
\hline 2 & $\begin{array}{l}\text { Genge hay } \\
\text { Lintreated straw }\end{array}$ & $\begin{array}{l}84.81 \\
87.99\end{array}$ & $\begin{array}{l}35^{\circ} \\
25^{\circ}\end{array}$ & & $\begin{array}{l}350 \\
250\end{array}$ \\
\hline 3 & $\begin{array}{l}\text { Genge hay } \\
\text { Soda straw I. }\end{array}$ & $\begin{array}{l}86.38 \\
90.61\end{array}$ & $\begin{array}{l}350 \\
250\end{array}$ & & $\begin{array}{l}350 \\
250\end{array}$ \\
\hline 4 & $\begin{array}{l}\text { Genge hay } \\
\text { Soda straw II }\end{array}$ & $\begin{array}{l}88.66 \\
90.33\end{array}$ & $\begin{array}{l}350 \\
300\end{array}$ & & $\begin{array}{l}350 \\
300\end{array}$ \\
\hline
\end{tabular}

2) Afterwards the lime straw, thus disintegrated and containing abut $82 \%$ of moisture, was mixed with concentrated fodder, and fed to live stock for 70 days at the Impcrial College of Agriculture and Forestry in Morioka. 15 kilos of it was caten daily by a horse, 11 kilos by a cow, and 4 kilos by a pig, with good result in regard to their boely weight and milk production. 
Table III. (Continued).

\begin{tabular}{|c|c|c|c|c|}
\hline Period & Fodder & $\begin{array}{l}\text { Try matter } \\
\%\end{array}$ & Ram No. I. & $\begin{array}{l}\text { ghit g. } \\
\text { Ram No. II. }\end{array}$ \\
\hline 5 & $\begin{array}{l}\text { Genge hay } \\
\text { Lime straw }\end{array}$ & $\begin{array}{l}86.66 \\
91.23\end{array}$ & $\begin{array}{l}350 \\
300\end{array}$ & $\begin{array}{l}350 \\
300\end{array}$ \\
\hline 6 & $\begin{array}{l}\text { Genge hay } \\
\text { Boiled straw }\end{array}$ & $\begin{array}{l}91.19 \\
9173\end{array}$ & $\begin{array}{l}350 \\
250\end{array}$ & $\begin{array}{l}350 \\
200\end{array}$ \\
\hline 7 & $\begin{array}{l}\text { Genge hay } \\
\text { Soda straw III. }\end{array}$ & $\begin{array}{l}91.19 \\
93.17\end{array}$ & $\begin{array}{l}350 \\
250\end{array}$ & $\begin{array}{l}350 \\
250\end{array}$ \\
\hline
\end{tabular}

The daiiy excretion of facces during each main periocl is as shown in the appendix, and the average quantity of dry matter per head per day is shown in the next table.

Table IV. Excretion in grams of the dry matter of the faeces.

\begin{tabular}{|c|c|c|c|}
\hline Period & Fodder & Kam I & Kam II \\
\hline I & Genge hay & 254.8 & 247.1 \\
\hline 2 & Untreated straw & 258.4 & 243.1 \\
\hline 3 & Soda straw I. $(0.75 \% \mathrm{NaOH})$ & 2133 & 208.5 \\
\hline 4 & Soda straw II. ( $1.5 \% \mathrm{NaOIL})$ & 234 I & 228.5 \\
\hline 5 & I.ime straw $(1 . \% \mathrm{CaO})$ & 249.7 & 259.9 \\
\hline 6 & Boiled straw & $26 \mathrm{I} \cdot 4$ & 235.6 \\
\hline 7 & Soda straw 111. $\langle 0.25 \% \mathrm{NaOH}\rangle$ & 275.8 & 272.1 \\
\hline
\end{tabular}

The digestibility of nutrients of Genge hay was calculated as follows, according to the clata of table III, IV, and V (a).

Table V.

Ist period:-Genge hay

a) Composition of dried substances.

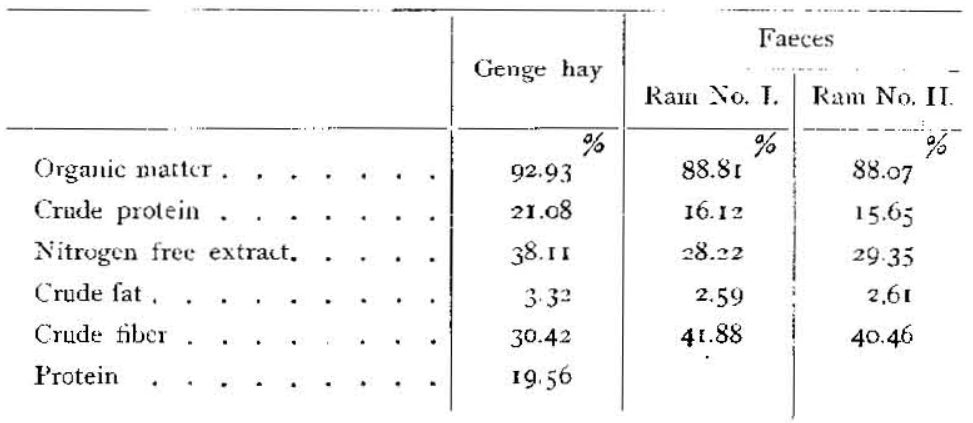


b) Calculation of digestion coefficients.

Ram No. I. Live weight 41.0-40.I K.

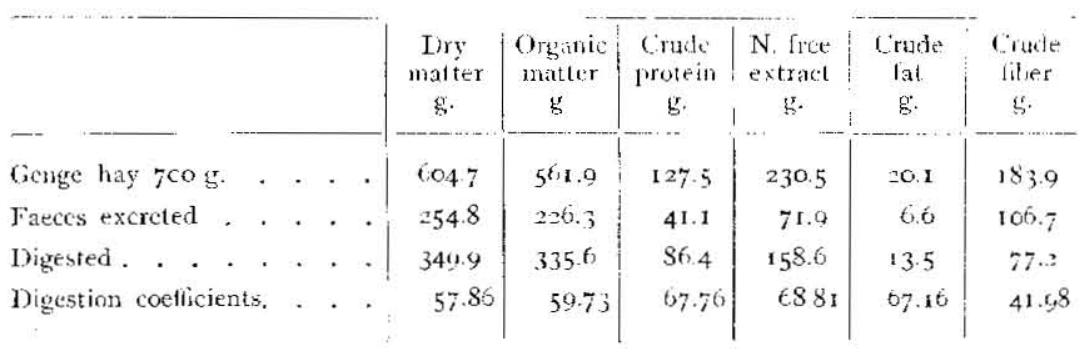

Ram No. IJ. I.ive weight $42.0-42.0 \mathrm{~K}$.

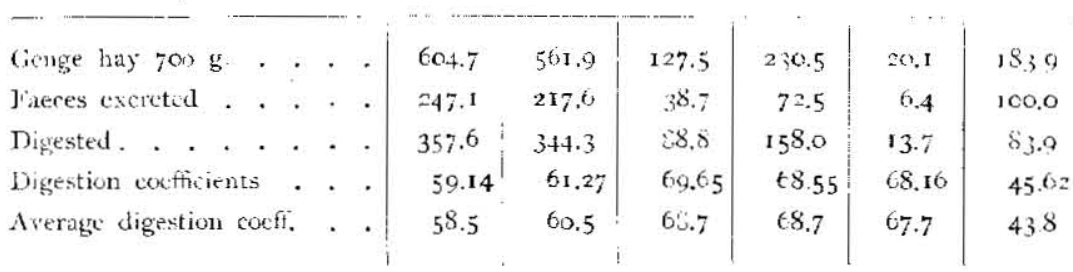

From these results it is seen, that the Genge hay contains about $13 \%$ of digestible protein, and its starch value is $38.3 \%$. This hay therefore can be considered to be one of the very good cuarse fodders in this country.

Next, with the help of the data shown in tables III, IV and VI (a), and the figures obtaincd as to the composition and rigestibility of the Genge hay, the digestibility of the untreated straw and the other treated straws were calculated as follows.

Table VI

2nd period:-Untreated straw.

a) Composition of dried substances.

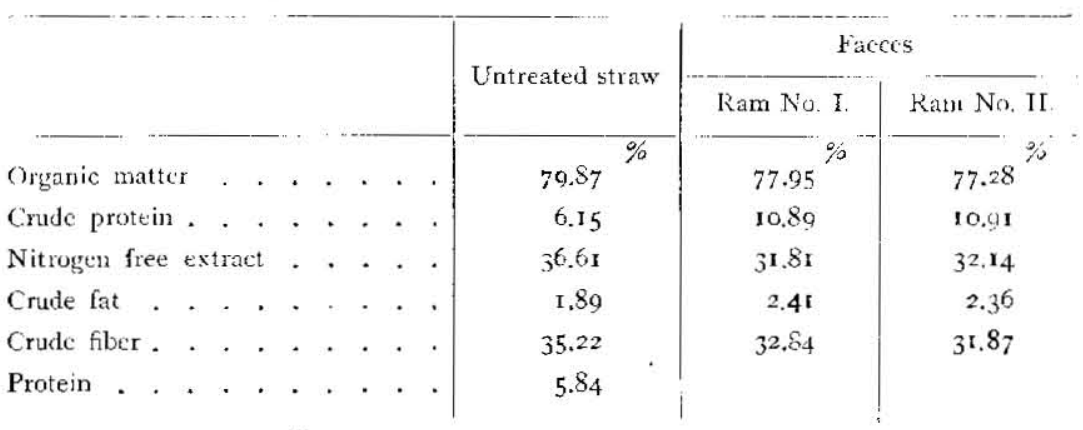


b) Calculation of digestion coefficients.

Ram No. I.

Live weight $40.05-39.0 \mathrm{~K}$.

\begin{tabular}{|c|c|c|c|c|c|c|c|c|c|}
\hline & & & & $\begin{array}{c}\text { Iry } \\
\text { malter } \\
\text { b. }\end{array}$ & $\begin{array}{c}\text { Oranic } \\
\text { mater } \\
\text { g. }\end{array}$ & $\begin{array}{c}\text { G xude } \\
\text { protein } \\
\text { \&s. }\end{array}$ & $\begin{array}{l}\text { N. free } \\
\text { extract } \\
\text { g. }\end{array}$ & $\begin{array}{l}\text { Crude } \\
\text { fat } \\
\text { g. }\end{array}$ & $\begin{array}{l}\text { Crude: } \\
\text { iiber } \\
\text { g. }\end{array}$ \\
\hline Genge hay $350 \mathrm{~g}$. . & . & . & . & $29 f, 8$ & 2758 & 62.6 & 11.3 .1 & 9.5 & 90.3 \\
\hline Lintreated straw $250 \mathrm{~g}$ & . & . & - & 220.0 & 175.7 & 1.3 .5 & 80.5 & 4.2 & 77.5 \\
\hline Amount consumed. . & + & . & . & 516.8 & .151 .5 & 76.5 & 10,36 & 14.1 & $\mathrm{~J} 67.9$ \\
\hline lacoes excreted . . & . & . & - & 258.4 & 201.4 & 28.1 & 322 & 6.2 & 84.9 \\
\hline Amount digested. . & . & . & . & 258.4 & 250.1 & 450 & I I I I.4 & 7.9 & 82.9 \\
\hline Digested from hay . & . & , & - & 171.7 & 16.7 .7 & $4^{2} .4$ & 77.8 & 6.6 & 37.9 \\
\hline Digested from striw . & . & . & . & 86.7 & 85.4 & 5.6 & 336 & I. 3 & 45.0 \\
\hline Digestion coeffecients & - & . & & 39.41 & $48.6 \mathrm{I}$ & $+1,4^{8}$ & 41.47 & .30 .95 & 58.06 \\
\hline
\end{tabular}

Ram No. II. Live weight $43.0-41 \cdot 3 \mathrm{~K}$.

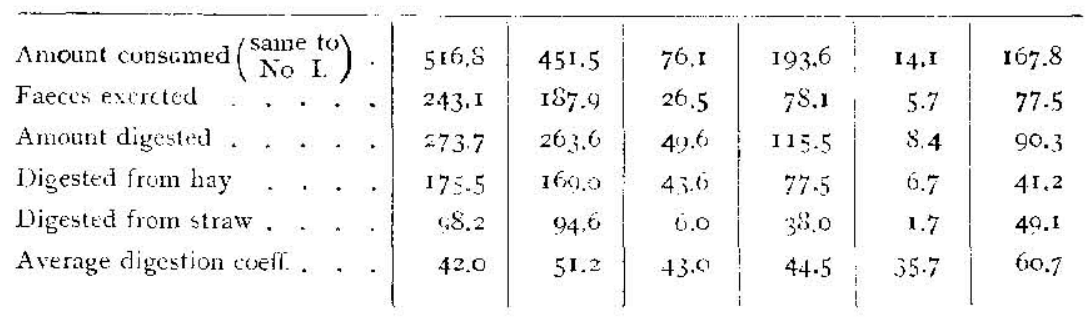

3rd period:- Soda strats I. $\quad(0.75 \%$ NaOII).

a) Composition of dried sulstances.

\begin{tabular}{|c|c|c|c|c|c|c|c|c|c|c|c|}
\hline \multirow{2}{*}{\multicolumn{3}{|c|}{+--}} & & & & & & \multirow{2}{*}{ Soda straw I. } & \multicolumn{2}{|c|}{ Fileces } & \\
\hline & & & & & & & & & \multirow{2}{*}{ Ram No. I } & \multicolumn{2}{|c|}{ Ram No II. } \\
\hline Organic matt & ter. & . & . & . & . & . & . . & $86.35^{\%}$ & & & $78.23^{\%}$ \\
\hline Crude protein & n. & . & . & . & . & . & . . & 5.75 & I 4.25 & & 14.32 \\
\hline Nitrogen free & e ext & lract & & . & . & . & . . & 38.62 & 30.45 & & 3027 \\
\hline Crude fat & . . & . & . & . & . & . & . . & 1.64 & 2.85 & & 3.01 \\
\hline Crude fiber . & . . & . & . & . & . & . & . . & 40.34 & 30,84 & & 30.63 \\
\hline Protein . & . . & . & . & . & . & . & . . & $4.7 \mathrm{I}$ & . & & \\
\hline
\end{tabular}


b) Calculation of digestion cocfficients.

Ram No. I.

Live weight $39.4-39.7 \mathrm{~K}$.

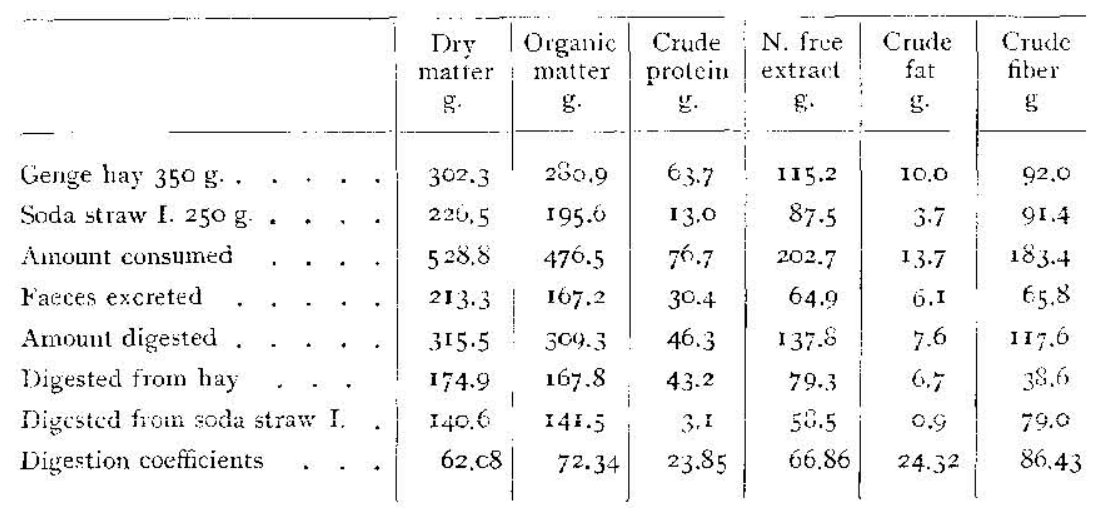

Ram No. II.

Live weight 4 I. - 4 I.4 K.

\begin{tabular}{|c|c|c|c|c|c|c|}
\hline Amount consumed $\left(\begin{array}{c}\text { same to } \\
\text { No. I. }\end{array}\right)$ & 528.8 & 476.5 & 76.7 & 202.7 & 13.7 & 183.4 \\
\hline Faeces excreted . . . & 208.5 & 163.1 & 29.9 & 63.1 & 6.3 & 63.9 \\
\hline Amount digested . . . & 320.3 & $3+3.4$ & 46.8 & 3.39 .6 & 7.4 & 119.5 \\
\hline Digested from hay . . & $1-8.8$ & 172.1 & 44.4 & 79.0 & 6.8 & 42.0 \\
\hline Digested from soda straw $\mathrm{I}$. & $14 \mathrm{I} .5$ & 141.3 & 2,4 & 60.6 & 0.6 & 77.5 \\
\hline Digestion coefficients. & 62.47 & 72.24 & 18.46 & 69.26 & 16.22 & 84.79 \\
\hline Average digestion cocfl. . & 62.3 & 72,3 & 21.2 & 68.1 & 20.3 & $8_{5} .6$ \\
\hline
\end{tabular}

$4^{\text {th }}$ period:- Soda straw II. $(1.5 \% \mathrm{NaOH})$.

a) Composition of dried substances.

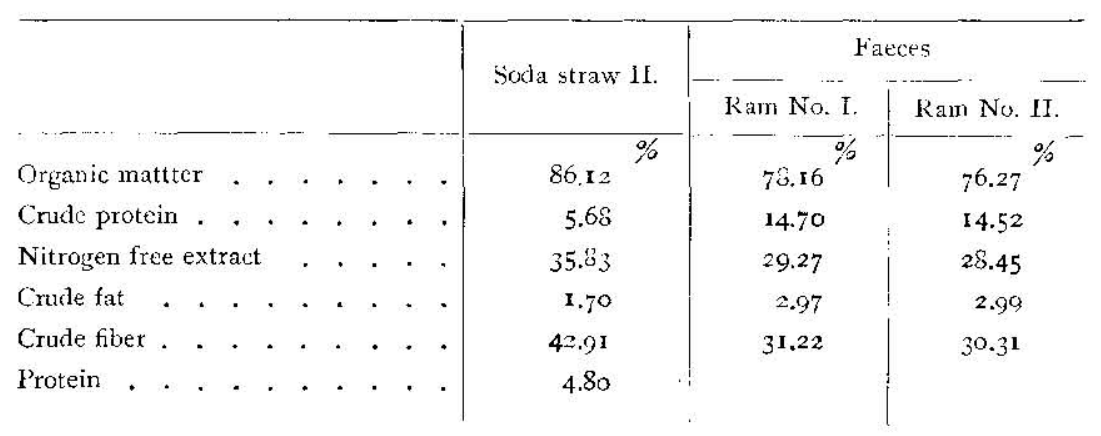


b) Caiculation of digestion coefficients.

Ram No. I. Live weight $39.6-38.9 \mathrm{~K}$.

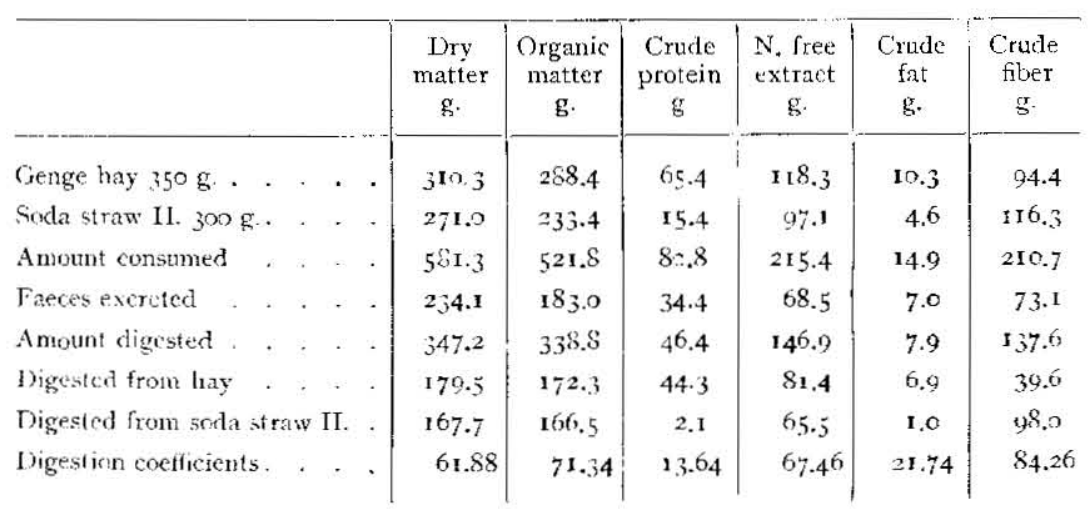

Ram No. II.

Live weight $40.8-41.2 \mathrm{~K}$.

\begin{tabular}{|c|c|c|c|c|c|c|}
\hline Anount consumed $\left(\begin{array}{cc}\text { samle to } \\
\text { No. } & 1\end{array}\right)$ & $581 \cdot 3$ & $52 \mathbf{r} .8$ & 80.8 & 215.4 & 14.9 & 210.7 \\
\hline Faeces evcreted , . . & $2 \approx 8.5$ & 174.3 & .33 .2 & 65.0 & 6.8 & 69.3 \\
\hline Amount digested . . . & 352.8 & 347.5 & 47.6 & 150.4 & 8.1 & 141.4 \\
\hline Bigested from hay . . . & 38.3 .5 & 176.7 & 45.6 & $\S 1 \cdot \mathrm{I}$ & 7.0 & 43.1 \\
\hline T)igested from soda straw 11. & $x 69.3$ & 170.8 & 2.0 & 60.3 & I.I & $3^{8} 8.3$ \\
\hline Digestion cocfticients. . & 62.47 & 73.18 & 12.99 & 71.37 & 23.91 & 84.52 \\
\hline Average digestion coeft. . & 62.2 & 72.3 & 13.3 & 69.4 & 22.8 & 84.4 \\
\hline
\end{tabular}

$5^{\text {th }}$ pericd:-Lime straw.

a) Composition of dried substances.

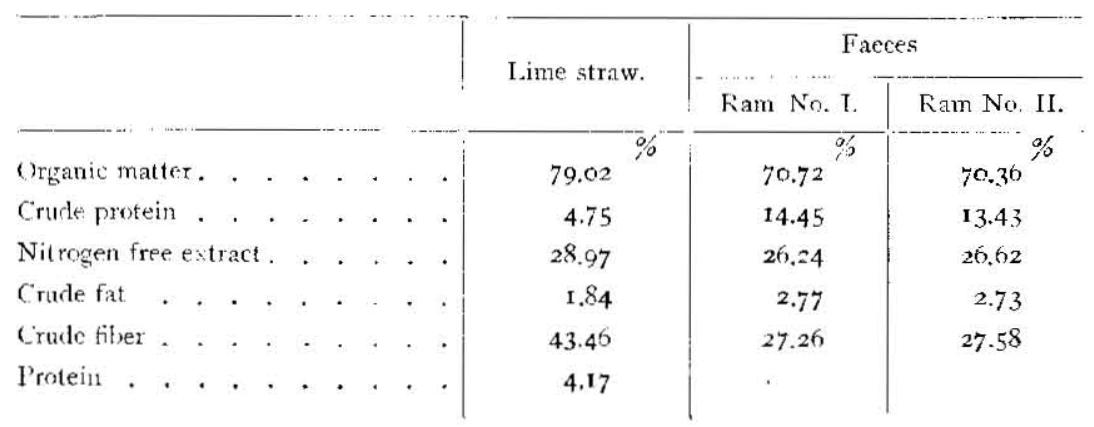


b) Calculation of digestion coefficients.

Ram No. I.

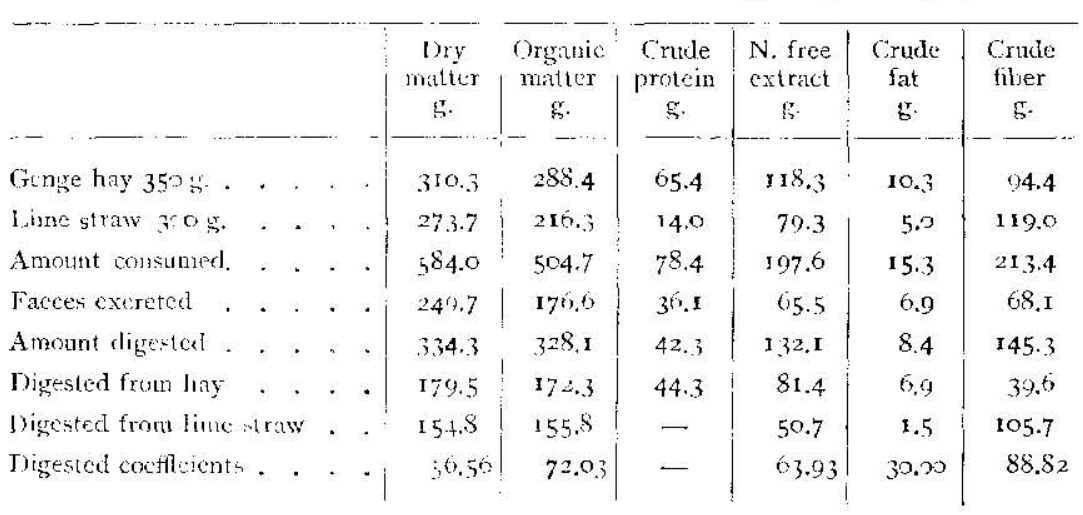

Ram No. II. Live weight $40.0-39.6 \mathrm{~K}$.

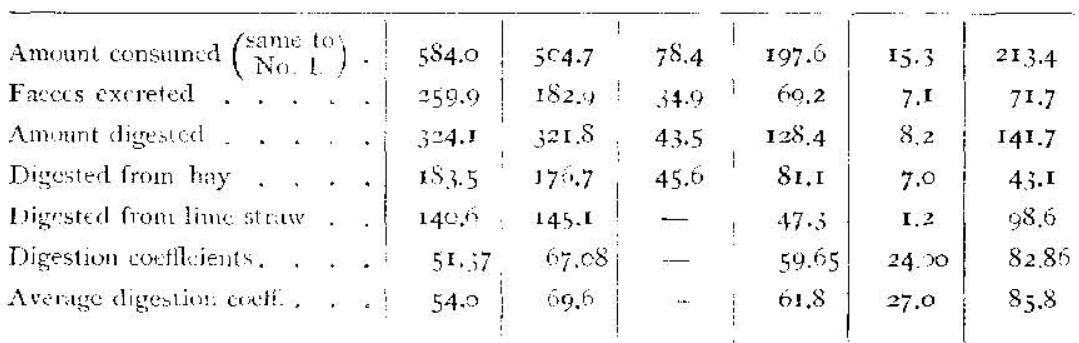

6th period:-Boiled straw.

a) Composition of chied substances.

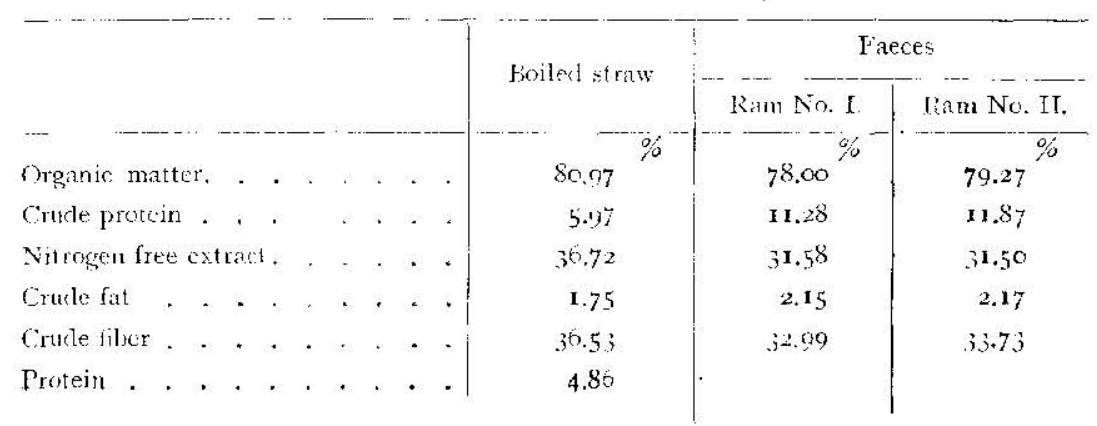


b) Calculation of digestion coefficients.

Ram No. I. Live weight 40.2-40.0 K.

\begin{tabular}{|c|c|c|c|c|c|c|c|c|}
\hline & & & $\begin{array}{c}\text { Dry } \\
\text { matler } \\
\text { g. }\end{array}$ & $\begin{array}{c}\text { Organic } \\
\text { wallex } \\
\mathrm{g} .\end{array}$ & $\begin{array}{c}\text { Crude } \\
\text { protein } \\
\text { s. }\end{array}$ & $\begin{array}{c}\text { N. free } \\
\text { extract } \\
g\end{array}$ & $\begin{array}{l}\text { Crude } \\
\text { fat } \\
g .\end{array}$ & $\begin{array}{l}\text { Crude } \\
\text { fiber } \\
\text { s. }\end{array}$ \\
\hline Gerge hay $350 \mathrm{~g}$. &. & . & $3 \mathrm{~J} 9.2$ & 296.6 & 67.3 & I 21.6 & 10.6 & 97.1 \\
\hline Boiled straw $250 \mathrm{~g}$ & .. & & 229.3 & 185.7 & 1.3 .7 & 84.2 & 4.0 & 8.8 \\
\hline Amourt consurncer. & . . & & 548.5 & 482.3 & 81,0 & $2>5.8$ & 14.6 & 180.9 \\
\hline Facces cxcreted &. & ${ }^{*}$ & 261.4 & 203.9 & 29.5 & 82.6 & 5.6 & 86.2 \\
\hline Smount digested. & .. & $\cdot$ & 287.1 & 278.4 & $5 x .5$ & 123.2 & 9.0 & 94.7 \\
\hline Digtsted from hay & . . & & 184.7 & 177.2 & 45.6 & 83.7 & 7.1 & 40.8 \\
\hline Jigested from boiled & strat & & $\mathrm{IO} 2.4$ & 101.2 & 5.9 & 39.5 & 1.9 & 53.9 \\
\hline Thigest ion conthents & . . & & 44.66 & 54.50 & 43.07 & $4^{6.9 \mathrm{I}}$ & 47.50 & 64.32 \\
\hline
\end{tabular}

Ram No. II.

Live weight $38.5-39$. I K.

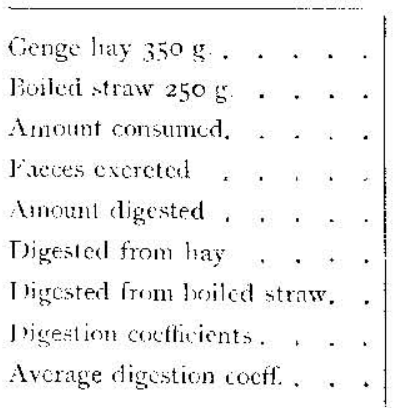

\begin{tabular}{|c|c|c|c|c|c|}
\hline 319.2 & 2966.6 & 67.3 & $1=1.6$ & 10.6 & 97.1 \\
\hline 18.5 & 148.6 & 11.0 & 67.4 & 3.2 & 67.0 \\
\hline 50.7 & 445.2 & 78.3 & $18 \% 3,0$ & 13.5 & 164.1 \\
\hline 235.6 & I 86.8 & $=8.0$ & 74.2 & $5 . \mathrm{I}$ & 70.5 \\
\hline 267.3 & $=58.4$ & 50.3 & 114.8 & 6.7 & $5_{4} 6$ \\
\hline 188.8 & 181.7 & 46.9 & $a_{3.4}$ & 7.2 & 44.3 \\
\hline $7^{8} .3$ & 76.7 & 3.4 & $3 \mathbf{I} .4$ & 1.5 & $40 ., j$ \\
\hline $4=67$ & 5I. If & 30,91 & 46.56 & 46.87 & $60.1_{4}$ \\
\hline 43.7 & 5.3 .1 & 37.0 & $4^{6} .7$ & 47.2 & 62.2 \\
\hline
\end{tabular}

th period:-Soda straw III. (0.25\% $\%$ NaH).

a) Composition of dried substances.

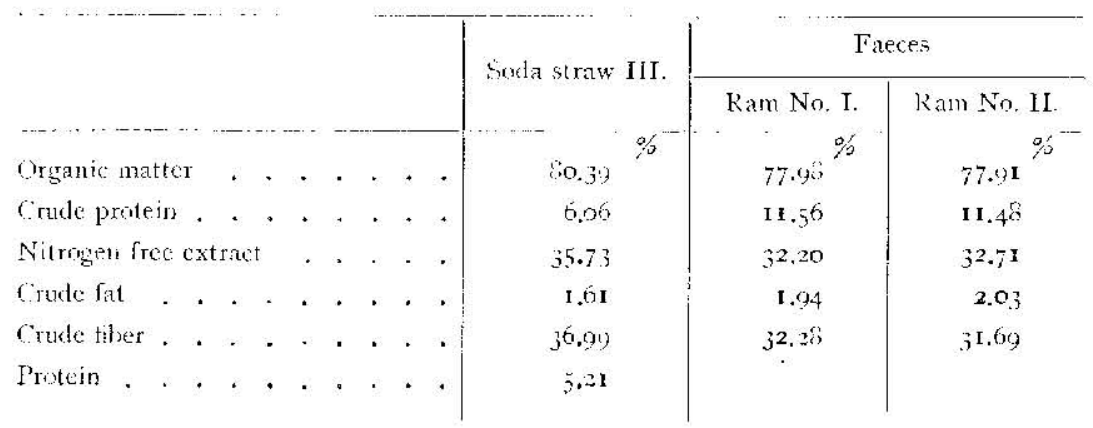


b) Calculation of digestion coefficients.

Ram No. I.

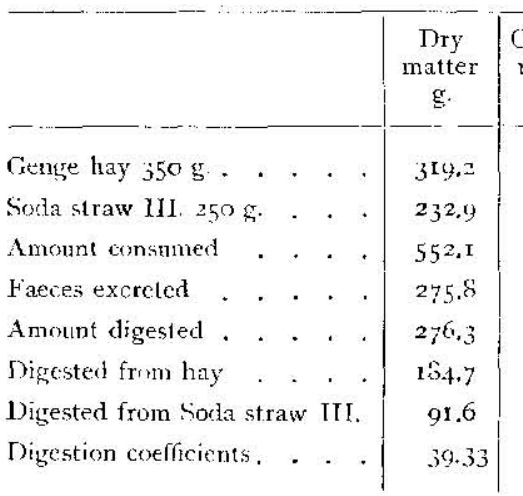

Ram No. II.
Live weight $40.0-39.4 \mathrm{~K}$.

\begin{tabular}{|c|c|c|c|c|}
\hline $\begin{array}{c}\text { Organic } \\
\text { matter } \\
\mathrm{g} .\end{array}$ & $\begin{array}{c}\text { Crude } \\
\text { protein } \\
\text { g. }\end{array}$ & $\begin{array}{l}\text { N. free } \\
\text { extract } \\
\text { g. }\end{array}$ & $\begin{array}{l}\text { Crude } \\
\text { fat } \\
\mathrm{g} .\end{array}$ & $\begin{array}{l}\text { Crude } \\
\text { fiber } \\
\mathrm{g} .\end{array}$ \\
\hline 206.6 & 67.3 & $12 t .6$ & 10.6 & $97 . x$ \\
\hline 187.2 & I 4.1 & $\delta_{3.2}$ & 3.7 & 56.1 \\
\hline 483.8 & $8 \mathrm{r} .4$ & 204.8 & 14.3 & 183.2 \\
\hline 215.1 & $3^{\mathbf{I}} \cdot 9$ & 88.6 & 5.4 & 89.0 \\
\hline 263.7 & 49.5 & I 16.0 & 8.9 & 94.2 \\
\hline 177.2 & 45.6 & $\delta_{3.7}$ & $7 . \mathrm{I}$ & 40.8 \\
\hline 91.5 & 3.9 & 32.3 & 1.8 & 53.4 \\
\hline 40.08 & 27.66 & $3^{8.82}$ & 48.65 & 62.02 \\
\hline
\end{tabular}

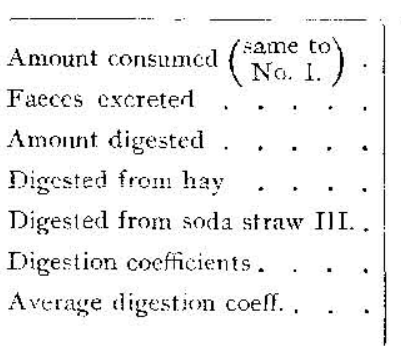

$55^{2.1}$
272.1
280.0
168.8
91.2
39.16
39.2

Live weight $40.4-39.0 \mathrm{~K}$.

In accordance with these data, the amount of digestible nutrients of the six sample fodders were calculated; also the starch value by KELINER's method for untreated straw, boiled straw and soda straw III. The same method was used to calculate the starch value in the case of the two latter because they were quite similar to the untreated straw in respect of the contents of digestible matters; however in the case of intensely disintegrated straw, such as soda straw I., II. and lime straw, Fingeriang's method (4) was used.

The results of this experiment coincided very well with those of the previous one (compare tables II and VII). They show that whilst scarcely any lignin or silica could be extracted by the $0.25 \mathrm{~g} \cdot \mathrm{NaOH}$ solution, $0.75 \%$ or $1.5 \%$ solution extracted a certain quantity of both; ancl the boiling milk of lime $(1 \% \mathrm{CaO})$ cxtracted the same quantity of lignin as abrve but no silica. The effect of caustic sorla on the rice straw was almost the same as on other kinds of straw reports of which 
Table VII. Composition and nutritive value of untreated straw, boiled straw and disintegrated straw

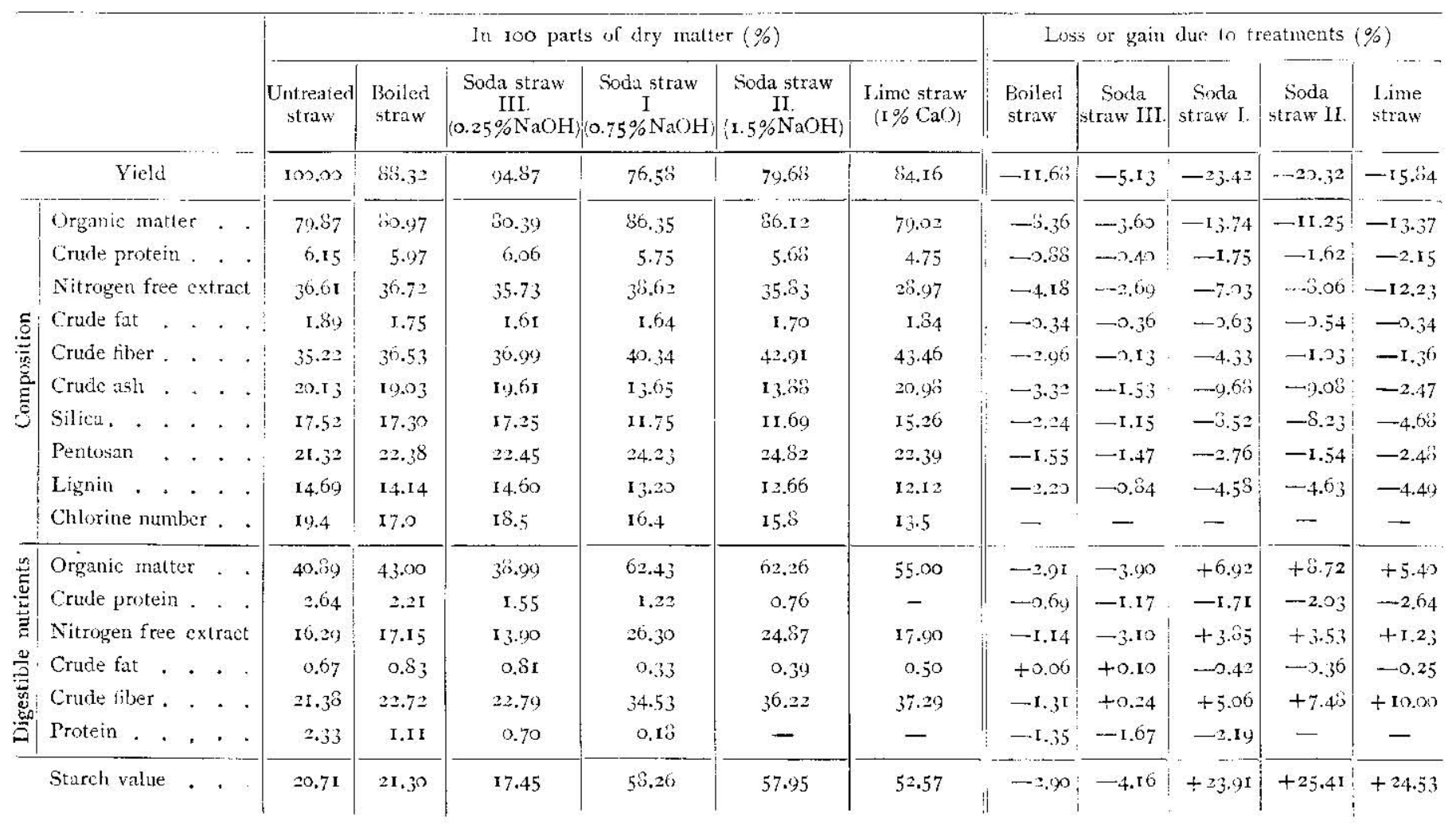


have been made by many investigators. But as regards the lime disintegration, Beckmaxy (2), Honcamp (6) and Marses (9) think the lignin combines with calcium to form a hard soluble compound which prevents further disintegration of the straw. However the author's cxperiments with rice straw do not suggest such a conclusion. The content of pentosan rather increased in the case of rice straw, which is the opposite of the results obtained in the case of other sorts of straw (9); at the same tine there was a total loss of pentosan of only I. $5-2.5 \%$.

The content of fiber remarlsably increased by the treatment with 0.75 or $1.5 \%$ sodium hydroxide and boiling milk of lime; that is to say about $40 \%$ of crude fiber was; contained in the soda straw I, II, and lime straw, whilst there was about $35 \%$ in the untreated, straw and also in the boiled straw and in the soda straw III. The content of nitrogen free extract was lardly changed, excopt in the case of lime disintegration. Both fat and protein decreased a good deal, but the absolute losses were negligible.

The digestibility of the total organic matter, of cruce fiber and of nitrogen free extract was remarkably promoted by the treatment either with 075 or 1.5 of sodium hydroxide cold solution. The line disintegration increased the contents of digestible organic matter and crude fiber to the same extent as with the cold caustic solla solution; but that of the digrestible nitroren free cxtract was only slightly increased. The amount of digestible fit and protein rlecreascd in every case, but the absolute amount of losses was negligible.

The starch value of the untreated straw was $20 \%$, which argree very well with the results of the wide recearches of ['rof. T. Katarama and $\mathrm{Mr}$. GoTo (not yet reported).

Comparing the nutritive values of these six sample fodkers, the starch value of soda straw I, II, and lime stritw was more than $50 \%$, nearly three times that of the untreated straw. Even when these was some loss of nutrients by the treatments, the tarch value incrased to about 2.5 times that of the untreated straw. The treatments with 0.25 sodium lydroxide solution and boiling water however had no noticedible effect on the starcli valuc.

As it is obvious from the above statements, the boiling of the straw exerts no effect on its nutritive valuc. However it must be rolmitted that the cattle can eat a larger amount of boikd straw owing to its good taste and lavour; moreover in winter it can supply a 
certain amount of heat energy to the animal body. In the case of boiling, however, it is rather advisable to use 8 parts of lime for 100 parts of straw, since the starch value can be easily doubled and also the taste improved.

The relation between the mutritive value and the quantity of incrusting substances can be explained from the above results as follows. The boiled straw and soda straw I[1. contained a large quantity of lignin and silica, but its starch vahe was low, noarly equal to the untreated straw; the soxla straw I. and II. contaned consicleably less lignin and silica, and was of high starch value; white the content of lignin in the lime straw approxinated to that of soda straw I. and II, and that of silica approximated to that of the original straw, yet its starch value was nearly equal to that of soda straw I. and II.

Hence it may be concluded that the increase in the nutritive value produced by disintegration is to be mainly attributed to the renoval of a certain amount of lignin, though the removal of the silica probably exerts no appreciable effect upon the mutritive value. Also it is seen that the increace of the starch value was not proportional to the recrease of the lignin content, honce that increase may be due not only to the decrease of lignin but also to the plysical and chemical (12) changes in the incruting substances.

\section{SUMTIRY}

The auther has investigated the effects of boiling with water and disintegration with alkalne solutions on the chenical composition and nutritive value of rice straw. The results are summarised as follows.

i) The starch value of the strow in dry matter was about 20 \%o, which agrees with the result of Prol. T. KaTarans's experiments.

2) The boiling for 3 hours in water did not change the chemical composition and mutritive value of the straw.

3) When the straw was solked in $0.25 \%$ sodium hydroxide solution for 4 hours, hardly any of its incrusting substances were removed, its digestibility was not promoted, and also the stach value, percont of dry matter, was nearly the same as that of the untreated stratw.

However when the straw was immersed 075 or 1.5 qa sollium hydroxide solution for 4 hours, or when it was boiled with the milk of lime ( 1 \% $\mathrm{CaO}$ ) for 3 houts, a consiclerable quantity of 
the incrusting substances were extracted, the amount of digestible matter was much increased, and also its starch value became as much as thrice that of the untrcated straw; actually it contained $53-58 \%$ of starch value in dry matter.

4) When the contents of the lignin and chlorine number decreased, the starch value of the treated straw increased, but not proportionally.

5) The data obtained in dry matter percentages were as follows:

\begin{tabular}{|c|c|c|c|c|c|c|}
\hline & $\begin{array}{c}\text { Uutreated } \\
\text { straw }\end{array}$ & $\begin{array}{l}\text { Boiled } \\
\text { straw }\end{array}$ & $\begin{array}{c}\text { Soda } \\
\text { straw IJI. } \\
0.25 \% \mathrm{NaOHI}\end{array}$ & $\begin{array}{c}\text { Soda } \\
\text { straw } \mathrm{I} \\
\text { (o. } 75 \% \mathrm{NaOII}\end{array}$ & $\begin{array}{c}\text { Soda } \\
\text { straw II. } \\
(1.5 \% \mathrm{NaOH})\end{array}$ & $\begin{array}{c}\text { I.ime } \\
\text { straw } \\
\text { I } \% \text { CaO }\end{array}$ \\
\hline $\begin{array}{c}\text { Content of digestible } \\
\text { organic malter. }\end{array}$ & 40.89 & 43.00 & 38.99 & 62.43 & 62.26 & 55.00 \\
\hline Chlorine number. . & 19.4 & 17.0 & 18.5 & 16.4 & 15.8 & 13.5 \\
\hline Content of lignin. . & 14.69 & $\mathrm{I} 4.14$ & 14.60 & 13.20 & 12.66 & 12.12 \\
\hline Starch value . . & 20.71 & $2 \mathbf{1} .30$ & 17.45 & $5^{8.26}$ & 57.95 & 52.57 \\
\hline
\end{tabular}

In conclusion the author expresses his best thanks to Prof. Dr. T. Kanayama under whose guidance this investigation was made, and also $\mathrm{Mr}$ S. ArHARA and Mr. J. YAsCNAGA for their valuable assistance during the feeding experiments.

Jan. 10, 1925. In the Laboratory of Animal Nutrition, Iepartment of Agriculture, Kyushu Imperial University.

\section{REFERENCES}

I. ARchiblal : Jour. Agr. Rescarch. 27, 245, 1924

2. Beckmayn: Sitzungsb. d. Preuss, Akad. d. Wissenschaft. 17, 275, 19r7.

3. Reckinvis: Biochem. Z. 139, 491, 1923.

4. Fingtrdini; : Iandw. Versuchsstat. 92, I, 1919.

5. Fingeking und Schmidt : Landw. Versuchistat. 94, I1 5 , I919.

6. HoNcaye und Batuañ: Iandw. Versuchsstat. 98, I, Igzi.

7. KFllNer: Die Fmährung d. Iandw. Nutyticre. ro. Aufl, 283, 1924.

8 KöNr: ['ntersuchung landwl. u. landw.- gewerbl, wicht. Stoffe. 5. Aufl, 1, 306.

9. Magnus: Theorie u. Praxis d. Strohaufschliessung. 1919.

so. MAHOOD and CABH: : J. Ind. Eng. Chem. 14, 727, 1922.

11. Ost und Wilkfing: Chem. Z. 34, 46r, 19I9.

12. Pringsheim und Masnis: IIOpfe-Seylek's physiol. Chem. 105, 179, igrg.

13. VOLharn: I andw. Versuchsstat. 58, 433, Igoj.

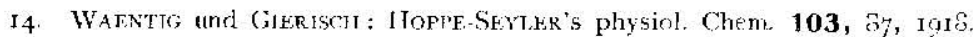

15. WAENTIF, und GLERISCH: Z. angew. Chem, 1, 173, igig.

I6. WistätTre und ZMimfister: Ber. d. deutsch. chem. Ges. 46. II, 2401, 1913. 
APPENDIX

Excretion of faeces

Ist period

Genge hay

\begin{tabular}{|c|c|c|c|c|c|c|c|c|}
\hline \multirow{2}{*}{$\mathbf{r g} 24$} & & \multirow[b]{2}{*}{ Temperature } & \multicolumn{3}{|c|}{ Ram No. I. } & \multicolumn{3}{|c|}{ Ram No. II. } \\
\hline & & & $\begin{array}{l}\text { Water } \\
\text { drink } \\
\text { I. }\end{array}$ & $\begin{array}{l}\text { Fresh } \\
\text { laeces } \\
\text { g. }\end{array}$ & $\begin{array}{c}\text { Dry } \\
\text { faeces } \\
\text { g. }\end{array}$ & $\begin{array}{l}\text { Water } \\
\text { drink } \\
\text { L. }\end{array}$ & $\begin{array}{c}\text { Fresh } \\
\text { faeces } \\
\text { g. }\end{array}$ & $\begin{array}{c}\text { Dry } \\
\text { Caeces } \\
\text { g. }\end{array}$ \\
\hline \multirow[t]{5}{*}{ September } & 26 & 23.5 & 1.8 & 754.5 & 251.5 & 3.15 & 654.8 & 224.2 \\
\hline & 27 & 2.3 .5 & 1.65 & $79 \mathrm{I} .5$ & 275.9 & 3.20 & 657.3 & 223.2 \\
\hline & 28 & 22.0 & 1.80 & 647.2 & 247.9 & 3.00 & 607.5 & 226.7 \\
\hline & 29 & 22.7 & 1.90 & 746.9 & 274.8 & 2.95 & $665 \cdot 3$ & 238.6 \\
\hline & 30 & 23.0 & 1.95 & 665.7 & 254.8 & 2.75 & $717 \cdot 3$ & 243.1 \\
\hline \multirow[t]{5}{*}{ October } & I & 23.3 & 1.90 & 663.5 & 235.9 & 2.40 & 858.5 & 280.8 \\
\hline & 2 & 25.0 & 2.10 & 634.0 & 241.0 & $3 \cdot 3 \circ$ & 924.1 & 281.3 \\
\hline & 3 & 25.3 & 2.20 & 572.0 & 230.9 & 3.40 & 975.0 & 277.6 \\
\hline & 4 & 25.0 & 2.05 & 653.0 & 266.6 & 3.20 & 835.0 & 243.1 \\
\hline & 5 & 24.5 & 2,10 & $6,8,0$ & 268.5 & 3.00 & 673.0 & $23^{2,1}$ \\
\hline \multicolumn{2}{|c|}{ Daily average } & 24.3 & 1.96 & 682.1 & 254.8 & 3.04 & 756.8 & 247.1 \\
\hline
\end{tabular}

2nd period

Untreated straw

\begin{tabular}{|c|c|c|c|c|c|c|c|}
\hline \multirow[b]{2}{*}{$\begin{array}{l}\text { July } \\
1924\end{array}$} & \multirow[b]{2}{*}{$\underset{\mathrm{C}^{\circ}}{\text { l'emperature }}$} & \multicolumn{3}{|c|}{ liam No. I. } & \multicolumn{3}{|c|}{ Ram No. II. } \\
\hline & & $\begin{array}{c}\text { Water } \\
\text { drink } \\
\text { I. }\end{array}$ & $\begin{array}{c}\text { Fresh } \\
\text { drink } \\
\text { g. }\end{array}$ & $\begin{array}{c}\text { Dry } \\
\text { faeces } \\
g .\end{array}$ & $\begin{array}{c}\text { Water } \\
\text { drink } \\
\text { L. }\end{array}$ & $\begin{array}{l}\text { Fresh } \\
\text { faeces } \\
\text { g. }\end{array}$ & $\begin{array}{c}\text { I)ry } \\
\text { faeces } \\
\mathrm{g}\end{array}$ \\
\hline 22 & 28.5 & 2.60 & 683.0 & 275.6 & $3 \cdot 35$ & 549.0 & 240.7 \\
\hline 23 & 29.7 & 2.70 & 601.0 & 254.9 & 3.65 & 601.5 & $24 \% .2$ \\
\hline 24 & 30,0 & 2.40 & 660.0 & 274.6 & 3.40 & $6_{32.0}$ & 279.3 \\
\hline 25 & 30.3 & 3.10 & 598.5 & 256.0 & $3.5 \circ$ & 552.5 & 241.8 \\
\hline 26 & 29.0 & 2.25 & 623.0 & 254.4 & 3.25 & 628.5 & 259.5 \\
\hline 27 & 30.3 & 2.90 & $6 \mathbf{I} 4.5$ & 259.1 & 3.25 & 532.5 & 234.7 \\
\hline 28 & 30.5 & 3.15 & $6 \mathbf{1} 8.0$ & $23^{8} .5$ & 3.65 & 577.0 & 223.4 \\
\hline 29 & 30.3 & 2,60 & 779.0 & 288.7 & 3.15 & $54 \% .0$ & 213.1 \\
\hline 30 & 30.5 & $3 \cdot 30$ & 635.0 & 245.8 & 3.85 & 709.0 & 243.9 \\
\hline $3^{I}$ & 30.5 & 3.10 & 686.0 & 236.8 & 3.10 & 683.5 & 246.9 \\
\hline Daily average & 30.0 & 2.83 & 649.8 & $25^{8.4}$ & $3-42$ & 606.4 & 243.1 \\
\hline
\end{tabular}


Sorla straw I $(0.75 \%$ NaOH)

\begin{tabular}{|c|c|c|c|c|c|c|c|c|}
\hline & \multirow[b]{2}{*}{$\begin{array}{l}\text { Oetober } \\
\text { rg24 }\end{array}$} & \multirow[b]{2}{*}{ lemperature } & \multicolumn{3}{|c|}{ Rami No. I. } & \multicolumn{3}{|c|}{ Ram Nó II. } \\
\hline & & & $\begin{array}{c}\text { Waler } \\
\text { drinh. } \\
1 .\end{array}$ & $\begin{array}{c}\text { Yresh } \\
\text { faccus } \\
g\end{array}$ & $\begin{array}{c}\text { l)y } \\
\text { faecis } \\
\text { g. }\end{array}$ & $\begin{array}{c}\text { Water } \\
\text { drink } \\
\text { I. }\end{array}$ & $\begin{array}{c}\text { lresh } \\
\text { faeces } \\
\xi\end{array}$ & $\begin{array}{c}\text { Dry } \\
\text { fateces } \\
\&\end{array}$ \\
\hline & I I & 20.3 & 1.20 & 471.0 & 2.35 .2 & 3.10 & $4 x ; 0$ & 218.4 \\
\hline & 12 & 23.0 & 1.65 & 51.1 .0 & 212.4 & 3.23 & 42.4 .0 & 207.2 \\
\hline & $\mathbf{I}_{j}$ & 22.0 & 1. (i) & 54200 & $2,32.8$ & .00 & .612 .0 & $22 y \cdot 3$ \\
\hline & 14 & 31.0 & 1. $) 5$ & 6420 & 220. & 2.95 & 3450 & $1 ; 7.3$ \\
\hline & I5 & 23.9 & $1,8 \mathrm{2}$ & 500.0 & 234.9 & 2.55 & -719.9 & 2.26 .8 \\
\hline & 16 & 21.5 & I. & $57: 03$ & I 44.6 & 3.03 & 417.2 & 222.5 \\
\hline & $\mathrm{I} ;$ & Iy.o & 1.60 & 66,10 & $23 \cdots 7$ & 3.60 & 3060 & 195.6 \\
\hline & 18 & 18.5 & I. 40 & 547.0 & 231.3 & 2.40 & $3: 12,0$ & $I(30.7$ \\
\hline & I9 & Iy.o & 1.50 & 6013.0 & 210.1 & 2.150 & 430.0 & $2 \mathbf{1} 9.7$ \\
\hline & 20 & 19.5 & 1.45 & 617.0 & 202.4 & 2.85 & 440.0 & 220.6 \\
\hline Daily & Average & 20.4 & 1.63 & 500.3 & $2 \mathbf{1}_{3 \cdot 3}$ & 3.01 & 422.3 & 200.5 \\
\hline
\end{tabular}

$4^{\text {th }}$ period

Soda straw II (i.5 co NaOH)

\begin{tabular}{|c|c|c|c|c|c|c|c|}
\hline \multirow[b]{2}{*}{$\begin{array}{c}\text { November } \\
\text { ry?24 }\end{array}$} & \multirow[b]{2}{*}{ Temperature } & \multicolumn{3}{|c|}{ Raul Ni. I. } & \multicolumn{3}{|c|}{ Ram Non. II. } \\
\hline & & $\begin{array}{c}\text { Water } \\
\text { drink } \\
\text { I.. }\end{array}$ & $\begin{array}{c}\text { Fresh } \\
\text { faeces } \\
\quad g .\end{array}$ & $\begin{array}{c}\text { Dry } \\
\text { faeces } \\
\text { g. }\end{array}$ & $\begin{array}{c}\text { Water } \\
\text { drink } \\
\text { r. }\end{array}$ & $\begin{array}{c}\text { Fresh } \\
\text { facces } \\
\text { gs }\end{array}$ & $\begin{array}{c}\text { Try } \\
\text { facoses } \\
g .\end{array}$ \\
\hline 3 & 15.5 & 1.50 & 606.0 & 267.9 & 2.00 & 521.0 & 222.8 \\
\hline 4 & 56.0 & 1.40 & 501.0 & 205.1 & 2.10 & 499.0 & $2 \mathrm{I} 8.8$ \\
\hline 5 & 106.0 & 1.35 & 647.0 & 207.9 & 1.75 & $f 8 \mathbf{1} .0$ & $21_{3} \cdot 9$ \\
\hline 6 & 13.5 & 1.25 & 5 I 6.0 & 220.3 & $\mathbf{1} .65$ & 518.0 & 226.8 \\
\hline 7 & 155 & 1.40 & $612 n^{\circ}$ & 261.9 & 2.20 & 495.0 & $20 \hat{3} .7$ \\
\hline 8 & 15.0 & 1.05 & 534.5 & 2.37 .8 & 1.80 & 613.0 & 2.40 .7 \\
\hline 9 & 130 & 1.05 & 600.0 & 241.7 & 1.45 & 632.5 & $=40.6$ \\
\hline 10 & 14.5 & 1,50 & 596,0 & 207.5 & 1.70 & 5040 & 202.3 \\
\hline II & $I_{4} .5$ & I. 20 & 557.5 & 220.1 & 1.60 & fiIi).5 & $2,43.7$ \\
\hline 12 & 15.0 & 1.25 & 700.5 & 270.7 & 1.85 & 699.0 & $26 \%, ;$ \\
\hline Daily Average & 14.9 & 1.35 & 593.1 & 234.1 & $\mathbf{1} . \delta \mathbf{I}$ & 550.7 & 223.5 \\
\hline
\end{tabular}


$5_{\text {th }}$ period

Lime straw ( o ó $\mathrm{CaO}$ )

\begin{tabular}{|c|c|c|c|c|c|c|c|}
\hline \multirow[b]{2}{*}{$\begin{array}{c}\text { Noreniber } \\
1924\end{array}$} & \multirow[b]{2}{*}{ Temperature } & \multicolumn{3}{|c|}{ Ram Na. I. } & \multicolumn{3}{|c|}{ Kam No. II. } \\
\hline & & $\begin{array}{c}\text { Water } \\
\text { driusk } \\
\text { L }\end{array}$ & $\begin{array}{c}\text { Firesh } \\
\text { faeces } \\
\text { g }\end{array}$ & $\begin{array}{c}\text { Jiry } \\
\text { faeces } \\
\text { g }\end{array}$ & $\begin{array}{c}\text { Water } \\
\text { drink } \\
\text { I. }\end{array}$ & $\begin{array}{l}\text { Fresh } \\
\text { faeces } \\
\text { g. }\end{array}$ & $\begin{array}{c}\text { Dry } \\
\text { faeces } \\
\text { g. }\end{array}$ \\
\hline 13 & 15.0 & $1 .+0$ & 501.5 & $=10.3$ & 1.60 & 657.5 & 235.2 \\
\hline 19 & 97.0 & I. 55 & 7.55 .5 & 256.1 & 1.30 & 640.5 & 261.4 \\
\hline 20 & 18.0 & 135 & 63.5 & $25: 5$ & 1.60 & 651.5 & $\because 73.3$ \\
\hline 21 & 16.5 & 1.20 & 860.0 & 251.6 & т.6о & 578.5 & 231.8 \\
\hline 22 & $1 ;: 5$ & 1.40 & $\lg 320$ & $267, \vdots$ & $\mathrm{r} .55$ & 607.5 & 279.2 \\
\hline 23 & 12.0 & T.I & $y=0.0$ & 249.8 & 1.25 & 706.4 & 283.4 \\
\hline 24 & $1: 0$ & 1.40 & 63.0 & 2613.6 & 1.65 & 553.5 & 214.4 \\
\hline 25 & 5.30 & 1.30 & 37.0 & 254.5 & 1.70 & $793 . \mathrm{C}$ & 2230.7 \\
\hline 20 & 14.0 & $\mathrm{I} .35$ & 249.0 & 241.0 & 1.70 & 624.5 & $250 . \mathrm{I}$ \\
\hline $2 \%$ & I 4.0 & 1.30 & 974.0 & 277.7 & 1.85 & 647.5 & 273.5 \\
\hline Daily Average & 14.6 & I. 34 & 874.5 & 249.7 & I.65 & 654.0 & 2599 \\
\hline
\end{tabular}

6th periud

Boiled straw

\begin{tabular}{|c|c|c|c|c|c|c|c|}
\hline \multirow[b]{2}{*}{$\begin{array}{c}\text { Felmuary } \\
\text { 1025 }\end{array}$} & \multirow[b]{2}{*}{$\begin{array}{c}\text { Temprature } \\
\mathrm{C}^{\circ}\end{array}$} & \multicolumn{3}{|c|}{ Kann No I. } & \multicolumn{3}{|c|}{ Ram No. II. } \\
\hline & & $\begin{array}{c}\text { Water } \\
\text { drink } \\
\text { r.. }\end{array}$ & $\begin{array}{l}\text { Fresh } \\
\text { faeces } \\
\text { g. }\end{array}$ & $\begin{array}{c}\text { Dry } \\
\text { faeces } \\
\text { g. }\end{array}$ & $\begin{array}{l}\text { Water } \\
\text { drinks } \\
\text { I. }\end{array}$ & $\begin{array}{c}\text { Fresh } \\
\text { faeces } \\
\text { g. }\end{array}$ & $\begin{array}{c}\text { Dry } \\
\text { faeces } \\
\text { g. }\end{array}$ \\
\hline 5 & $1 \% .0$ & 2.05 & $8.30 . \mathrm{c}$ & 279.9 & 1.85 & 511.0 & 227.9 \\
\hline 6 & 18.0 & 2.10 & 694.0 & 2.47 .6 & 2.10 & 518.0 & 246.3 \\
\hline 7 & 16.5 & 1.50 & 645.0 & 220.5 & 1.80 & 4630 & 222.9 \\
\hline 3 & $I 2.5$ & $1.7^{0}$ & 763.0 & 293.3 & 1.75 & 4.345 & $20 \% .0$ \\
\hline 9 & I I,O & $x, 60$ & 512.0 & 259.2 & 2.00 & 445.0 & 218.3 \\
\hline 10 & I 1.0 & 1.50 & 574.0 & 264.3 & I.55 & 410.0 & 197.3 \\
\hline In & $\mathbf{I} 2.0$ & 1.60 & 673.5 & 290.5 & 1.45 & $55 \mathrm{I} .0$ & 257.1 \\
\hline 12 & 10.5 & $\mathrm{~T} .55$ & 757.0 & 204.4 & 1.80 & $5: 6.0$ & 269.9 \\
\hline $\mathbf{I} 3$ & I1.0 & 1.50 & $5 \div 1.5$ & 224.2 & $=05$ & 627.0 & 266.6 \\
\hline I 4 & II.O & I. 75 & 771.5 & 271.7 & 1.80 & 513.5 & 241.6 \\
\hline Daily Average & $I_{3.2}$ & I.7I & 674.2 & 261.4 & $x .62$ & 506.7 & 235.6 \\
\hline
\end{tabular}




\begin{tabular}{|c|c|c|c|c|c|c|c|c|}
\hline \multirow{2}{*}{\multicolumn{2}{|c|}{$\begin{array}{l}\text { February } \\
\text { I } 925\end{array}$}} & \multirow[b]{2}{*}{ Temperature } & \multicolumn{3}{|c|}{ Kan No. I. } & \multicolumn{3}{|c|}{ Ram No. II. } \\
\hline & & & $\begin{array}{c}\text { Water } \\
\text { drink } \\
\text { L }\end{array}$ & $\begin{array}{l}\text { Fresh } \\
\text { faeces } \\
\text { g. }\end{array}$ & $\begin{array}{l}\text { Dry } \\
\text { faeces } \\
\text { g. }\end{array}$ & $\begin{array}{c}\text { Water } \\
\text { drink } \\
\text { L. }\end{array}$ & $\begin{array}{c}\text { Fresh } \\
\text { faeces } \\
g\end{array}$ & $\begin{array}{l}\text { Dry } \\
\text { facies } \\
\text { g }\end{array}$ \\
\hline & 20 & II.O & $1.7^{\mathrm{O}}$ & 751.0 & 295.6 & 1,80 & 601.0 & 252.6 \\
\hline & 21 & 11.5 & 1.65 & 836.0 & 313.7 & 1.70 & 690.5 & 279.4 \\
\hline & 22 & II.O & 2.00 & $7 \hat{3} 7.0$ & $282 . \mathrm{I}$ & 2.05 & 643.5 & 314.1 \\
\hline & 23 & $5 \cdot 5$ & 1.60 & 818.5 & 249.0 & 1.20 & 597.5 & 201.2 \\
\hline & 24 & 7.0 & 1.50 & 671.5 & 252,2 & 1.30 & 624.0 & 271.8 \\
\hline & 25 & 6.0 & 1.20 & 784.0 & 267.6 & 1.40 & 605.5 & 2066.1 \\
\hline & 26 & 7.0 & 1.70 & 794.5 & 292.8 & I. 55 & 594.0 & 262.3 \\
\hline & 27 & 6.5 & 1.65 & 317.5 & $2 ; 2.9$ & 1,40 & 577.0 & 246.2 \\
\hline & 28 & 7.0 & 1.35 & 867.5 & 302.0 & 1.85 & 634.0 & 272.0 \\
\hline \multirow[t]{3}{*}{ May } & I & 8.0 & 1.70 & 810.5 & 275.9 & 1.70 & 724.5 & 288.5 \\
\hline & 2 & 8.5 & 2.75 & 796.5 & 248.7 & 2.90 & 652.5 & 281.0 \\
\hline & 3 & 9.5 & 1.80 & 781.5 & 256.2 & 1.65 & 723.5 & 270.5 \\
\hline Daily & Average & 8.2 & $1.7^{2}$ & 793.0 & 275.8 & $\mathrm{I} .7 \mathrm{I}$ & 639.4 & 272.1 \\
\hline
\end{tabular}

